\title{
Diagnostic chest X-rays and breast cancer risk among women with a hereditary predisposition to breast cancer unexplained by a $B R C A 1$ or BRCA2 mutation
}

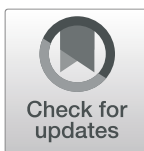

Maximiliano Ribeiro Guerra 1,2,3,4,5, Juliette Coignard ${ }^{1,2,3,4}$, Séverine Eon-Marchais 1,2,3,4, Marie-Gabrielle Dondon 1,2,3,4, Dorothée Le Gal 1,2,3,4, Juana Beauvallet ${ }^{1,2,3,4}$, Noura Mebirouk ${ }^{1,2,3,4}$, Muriel Belotti, Olivier Caron ${ }^{7}$, Marion Gauthier-Villars ${ }^{6}$, Isabelle Coupier ${ }^{8,9}$, Bruno Buecher $^{6}$, Alain Lortholary ${ }^{10}$, Jean-Pierre Fricker ${ }^{11}$, Paul Gesta ${ }^{12}$, Catherine Noguès ${ }^{13,14}$, Laurence Faivre ${ }^{15,16}$, Pascaline Berthet ${ }^{17}$, Elisabeth Luporsi ${ }^{18}$, Capucine Delnatte ${ }^{19}$, Valérie Bonadona ${ }^{20,21,22}$, Christine M. Maugard ${ }^{23,24}$, Pascal Pujol ${ }^{8,9}$, Christine Lasset ${ }^{20,21,22}$, Michel Longy ${ }^{25}$, Yves-Jean Bignon ${ }^{26}$, Claude Adenis-Lavignasse ${ }^{27}$, Laurence Venat-Bouvet ${ }^{28}$, Hélène Dreyfus $^{29,30}$, Laurence Gladieff $^{31}$, Isabelle Mortemousque ${ }^{32}$, Séverine Audebert-Bellanger ${ }^{33}$, Florent Soubrier ${ }^{34}$, Sophie Giraud ${ }^{35}$, Sophie Lejeune-Dumoulin ${ }^{36}$, Jean-Marc Limacher ${ }^{37}$, Jean Chiesa ${ }^{38}$, Anne Fajac ${ }^{39}$, Anne Floquet ${ }^{25}$, François Eisinger ${ }^{13,14}$, Julie Tinat ${ }^{40}$, Sandra Fert-Ferrer ${ }^{41}$, Chrystelle Colas ${ }^{6,42}$, Thierry Frebourg ${ }^{43^{\wedge}}$, Francesca Damiola ${ }^{44}$, Laure Barjhoux ${ }^{45}$, Eve Cavaciuti ${ }^{1,2,3,4}$, Sylvie Mazoyer ${ }^{46}$, Anne Tardivon ${ }^{47}$, Fabienne Lesueur ${ }^{1,2,3,4}$, Dominique Stoppa-Lyonnet ${ }^{6,48,49}$ and Nadine Andrieu ${ }^{1,2,34^{*}}$ (D)

\begin{abstract}
Background: Diagnostic ionizing radiation is a risk factor for breast cancer (BC). BC risk increases with increased dose to the chest and decreases with increased age at exposure, with possible effect modification related to familial or genetic predisposition. While chest $\mathrm{X}$-rays increase the $\mathrm{BC}$ risk of BRCA1/2 mutation carriers compared to non-carriers, little is known for women with a hereditary predisposition to $B C$ but who tested negative for a BRCA1 or BRCA2 (BRCA1/2) mutation.

Methods: We evaluated the effect of chest $X$-rays from diagnostic medical procedures in a dataset composed of 1552 BC cases identified through French family cancer clinics and 1363 unrelated controls. Participants reported their history of $X$-ray exposures in a detailed questionnaire and were tested for 113 DNA repair genes. Logistic regression and multinomial logistic regression models were used to assess the association with BC.
\end{abstract}

\footnotetext{
* Correspondence: nadine.andrieu@curie.fr

Thierry Frebourg is deceased.

${ }^{1}$ INSERM, U900, Paris, France

${ }^{2}$ Institut Curie, Paris, France

Full list of author information is available at the end of the article
}

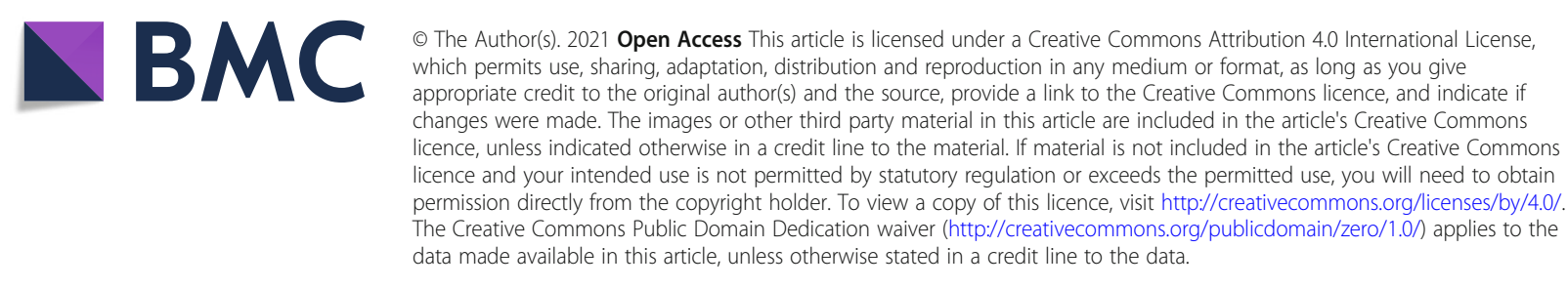


Results: Chest X-ray exposure doubled BC risk. A 3\% increased BC risk per additional exposure was observed. Being 20 years old or younger at first exposure or being exposed before first full-term pregnancy did not seem to modify this risk. Birth after 1960 or carrying a rare likely deleterious coding variant in a DNA repair gene other than BRCA1/2 modified the effect of chest $X$-ray exposure.

Conclusion: Ever/never chest X-ray exposure increases BC risk 2-fold regardless of age at first exposure and, by up to 5 -fold when carrying 3 or more rare variants in a DNA repair gene.

Further studies are needed to evaluate other DNA repair genes or variants to identify those which could modify radiation sensitivity. Identification of subpopulations that are more or less susceptible to ionizing radiation is important and potentially clinically relevant.

Keywords: Breast cancer, X-ray exposure, Low dose, High-risk population, DNA repair genes

\section{Introduction}

Medical diagnostic ionizing radiation is a known risk factor for the development of primary breast cancer (BC). $\mathrm{BC}$ risk associated with exposure to such radiation increases with radiation dose and decreases with age of exposure [1, 2]. Periods of high breast cell proliferation, such as during puberty and pregnancy, are associated with increased levels of DNA synthesis and thus may make breast tissue particularly susceptible to the carcinogenic effects of radiation [1,2]. This susceptibility to radiation may be exacerbated for women with a familial/ genetic predisposition [3-7] and particularly for women carrying genetic variants altering DNA repair mechanisms that may lead to cellular radio-sensitivity [8]. Among studies conducted in the general population, few have evaluated the effect of medical radiation exposures according to family history of $\mathrm{BC}[6,7,9-12]$, and only two studies found a stronger dose response for patients with relatives affected than for patients with no family history $[7,9]$. Among studies involving women carrying a BRCA1 or BRCA2 (BRCA1/2) mutation, some found an association between chest $\mathrm{X}$-ray exposure and $\mathrm{BC}$; almost all of these studies showed that early exposure may be a risk factor for $\mathrm{BC}[3-5,13-18]$. For women with a non-BRCA1/2 hereditary predisposition to $\mathrm{BC}$, little is known about the effect of chest radiation exposures and knowledge of such an effect may have clinical relevance. Therefore, we evaluated the effect of low-dose radiation exposure from diagnostic medical procedures on $\mathrm{BC}$ risk in women attending family cancer clinics, but not carrying a BRCA1/2 mutation [19]. We also evaluated whether carrying a rare variant in a DNA repair gene other than BRCA1/2 modified the effect of chest $\mathrm{X}$-ray exposure.

\section{Methods}

\section{Study population}

The GENESIS (for GENE SISter) study was initially set up to investigate the missing heritability of $\mathrm{BC}$ in a highrisk population with unrelated controls for conducting association studies [19]. GENESIS involved the recruitment of a study population enriched for susceptibility factors by case selection based on familial criteria (Supplementary Method Section), with consideration of environmental factors. Index cases were identified by the national network of family cancer clinics (Genetics and Cancer Group of UNICANCER) (i.e., 42 centers) when eligible, i.e., when diagnosed with infiltrating mammary or ductal adenocarcinoma, negative for $B R C A 1$ and $B R C A 2$ mutations, and had a sister with $\mathrm{BC}$. The mutation screening strategy used was similar for all the clinics. Each family cancer clinic of the national network invited index cases to participate in the GENESIS study by letter or during consultations informing patients of their BRCA1/2 negative results and referred them to the coordinating center (Curie Institute, Paris, France) if index cases consented to participate. Index cases contacted unrelated unaffected friends or colleagues with years of birth matched to \pm 3 years and invited them to participate and referred those who accepted to participate to the coordinating center. The coordinating center organized the enrollment of index cases and their unrelated controls, collection of questionnaires, family, and clinical data of participants (Fig. 1).

All women completed a questionnaire on environmental, lifestyle and reproductive factors, and family history of cancer. Blood samples were collected at participation (see Supplementary Methods Section in Additional file 1.doc). We considered only women reporting European ancestry (i.e., over $95 \%$ of the study population) for this evaluation.

\section{Exposure to low-dose radiation to the chest}

Participants reported their history of chest X-ray exposure from diagnostic/screening medical procedures in a detailed questionnaire at the time of their recruitment. We considered procedures where the thoracic region was exposed such as conventional radiography, fluoroscopy, computed tomography, and scintigraphy (excluding mammograms). Age at exposure, number of exposures, type of 


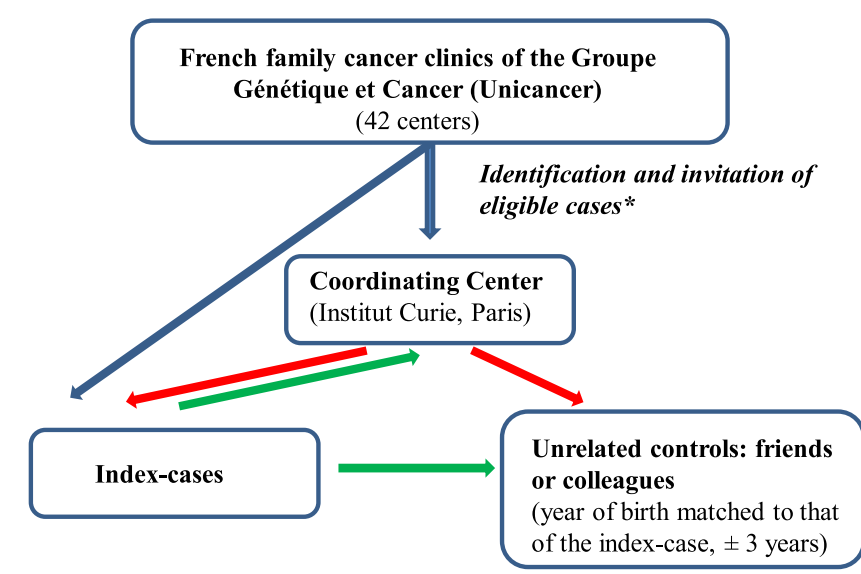

\begin{abstract}
* Cases with infiltrating mammary or ductal adenocarcinoma, negative for $B R C A 1$ and $B R C A 2$ mutations, and a sister with breast cancer (Molecular diagnosis performed between 2003 and 2013)
\end{abstract}

Unrelated controls: friends (year of birth matched to that of the index-case, \pm 3 years)

Fig. 1 Recruitment process for index cases and unrelated controls

procedure, and reason(s) for performing the examination were also documented.

To estimate lifetime exposure, pulmonary radiological examinations, preoperative radiological examinations, and radiological examinations of the heart and thoracic vessels were taken into account for all the reported procedures.

To exclude procedures that could have been performed because of $\mathrm{BC}$ diagnosis, we included exposures that occurred up to 1 year prior to $\mathrm{BC}$ diagnosis for cases and 1 year prior to the date of questionnaire completion for controls.

For each type of procedure, information on lifetime exposure (ever/never), number of exposures, and age at first exposure were collected. Variables considered in the analyses were ever versus never exposed, number of exposures, age at first exposure, and timing of first exposure relative to the first full-term pregnancy (FFTP).

We excluded 52 women who underwent radiotherapy for a benign disease 1 year prior to age at censoring (2.19\% cases, $1.23 \%$ controls). Among cases, we also excluded 10 women $(0.63 \%)$ who underwent radiotherapy for a cancer other than $\mathrm{BC}$ before their $\mathrm{BC}$ diagnosis.

\section{DNA repair-related variants}

We previously assessed the contribution of rare germline deleterious or likely deleterious variants (with minor allele frequency $>0.5 \%$ in controls) in 113 DNA repair genes in familial $\mathrm{BC}$ by performing targeted sequencing of the entire coding sequence in 1207 cases and 1199 controls from GENESIS. Detailed information on the selection of genes, sequencing procedure and variants filtering and annotation is described in Girard et al. [20] (see Supplementary Methods Section in Additional file 1.doc). Published results of the association tests per gene are shown in Table 1. Sequencing data were available for $82.5 \%$ of the GENESIS subjects investigated in the present study. There was no difference in the distribution of the characteristics between the subsets of cases and controls with and without sequencing data (see Supplemental Table 1 in Additional file 2.doc).

Because each gene has very low deleterious or likely deleterious variant frequencies (frequency of the pool of variants for each gene ranged between $0 \%$ and $4.1 \%$ in controls) and thereby stratification by X-ray exposure and by gene led to very small numbers of subjects or even no subjects, we grouped the genes according to the value of their association with $\mathrm{BC}$, i.e., the odds ratio (OR) point estimate obtained in the study by Girard et al. (Table 1) and classified them as follows: Group "Low" including genes with $\mathrm{OR}<0.9$; Group "No Effect," including genes with $0.9 \leq \mathrm{OR} \leq 1.1$ and Group "High," including genes with $\mathrm{OR}>1.1$. An individual could be assigned to more than one group if carrying variants in genes belonging to different groups.

\section{Statistical analyses}

To assess the association between chest X-ray exposure and risk of $\mathrm{BC}$, we used logistic regression models. To assess whether the association varied according to tumor estrogen receptors (ER) status, we used multinomial regression models. Analyses were adjusted for age at censoring, which was calculated as the age at diagnosis for cases, and the age at interview for controls. Other 
Table 1 Association of rare coding variants with breast cancer, for the 113 DNA repair genes sequenced in the GENESIS population [20]

\begin{tabular}{|c|c|c|c|c|c|}
\hline \multirow[t]{2}{*}{ Gene } & \multicolumn{5}{|l|}{ Any variant } \\
\hline & Control carriers & Case carriers & $\mathrm{OR}^{\mathrm{a}}(95 \% \mathrm{Cl})$ & $P$ value & Group $^{b}$ \\
\hline BABAM1/MERIT40 & 4 & 2 & $0.5(0.1,2.8)$ & 0.43 & Low \\
\hline$B A C H 1$ & 22 & 21 & $0.8(0.4,1.5)$ & 0.55 & Low \\
\hline BRCC3/BRCC36 & 3 & 1 & $0.3(0.0,3.2)$ & 0.34 & Low \\
\hline BRE & 11 & 7 & $0.6(0.2,1.6)$ & 0.35 & Low \\
\hline $\mathrm{CDH} 1$ & 14 & 11 & $0.8(0.4,1.7)$ & 0.54 & Low \\
\hline CDKN1A & 13 & 11 & $0.8(0.4,1.9)$ & 0.66 & Low \\
\hline COBRA1 & 6 & 4 & $0.7(0.2,2.4)$ & 0.55 & Low \\
\hline$D L G 1$ & 25 & 15 & $0.6(0.3,1.2)$ & 0.12 & Low \\
\hline ESR1 & 10 & 6 & $0.6(0.2,1.5)$ & 0.26 & Low \\
\hline EXO1 & 45 & 37 & $0.8(0.5,1.3)$ & 0.41 & Low \\
\hline FAM175A/ABRAXAS & 7 & 5 & $0.7(0.2,2.3)$ & 0.56 & Low \\
\hline FANCA & 19 & 15 & $0.8(0.4,1.6)$ & 0.53 & Low \\
\hline FANCD2 & 20 & 15 & $0.7(0.4,1.4)$ & 0.33 & Low \\
\hline FANCF & 6 & 5 & $0.8(0.3,2.8)$ & 0.77 & Low \\
\hline FANCG & 6 & 4 & $0.7(0.2,2.4)$ & 0.55 & Low \\
\hline FANCI & 22 & 13 & $0.6(0.3,1.2)$ & 0.13 & Low \\
\hline IRS2 & 13 & 9 & $0.7(0.3,1.5)$ & 0.33 & Low \\
\hline KIAA1967 & 22 & 17 & $0.8(0.4,1.5)$ & 0.41 & Low \\
\hline LIG4 & 15 & 13 & $0.7(0.3,1.6)$ & 0.46 & Low \\
\hline MLH3 & 21 & 10 & $0.5(0.2,1.0)$ & 0.06 & Low \\
\hline MUS81 & 10 & 7 & $0.6(0.2,1.6)$ & 0.30 & Low \\
\hline MYC & 2 & 2 & $0.8(0.1,5.5)$ & 0.78 & Low \\
\hline NAT1 & 3 & 1 & $0.4(0.0,3.4)$ & 0.37 & Low \\
\hline PMS2 & 22 & 16 & $0.7(0.3,1.3)$ & 0.24 & Low \\
\hline POLH & 13 & 5 & $0.4(0.1,1.1)$ & 0.07 & Low \\
\hline POLQ & 43 & 36 & $0.8(0.5,1.2)$ & 0.43 & Low \\
\hline PRKAA2 & 8 & 3 & $0.4(0.1,1.5)$ & 0.16 & Low \\
\hline RAD51D/RAD51L3 & 9 & 4 & $0.4(0.1,1.4)$ & 0.17 & Low \\
\hline RAD54L & 21 & 12 & $0.6(0.3,1.2)$ & 0.14 & Low \\
\hline RTEL1 & 20 & 8 & $0.4(0.2,0.9)$ & 0.03 & Low \\
\hline TIMELESS & 28 & 23 & $0.8(0.5,1.4)$ & 0.44 & Low \\
\hline TP53BP1 & 27 & 21 & $0.8(0.5,1.5)$ & 0.51 & Low \\
\hline TP63 & 6 & 3 & $0.5(0.1,2.0)$ & 0.33 & Low \\
\hline$\pi T / 2$ & 9 & 7 & $0.8(0.3,2.2)$ & 0.67 & Low \\
\hline WDR48 & 15 & 10 & $0.7(0.3,1.5)$ & 0.36 & Low \\
\hline$X R C C 1$ & 31 & 21 & $0.7(0.4,1.2)$ & 0.14 & Low \\
\hline APEX 1 & 10 & 10 & $1.0(0.4,2.4)$ & 0.98 & No effect \\
\hline$A R$ & 32 & 31 & $1.0(0.6,1.6)$ & 0.94 & No effect \\
\hline ATR & 30 & 29 & $1.0(0.6,1.6)$ & 0.92 & No effect \\
\hline BAP1 & 4 & 4 & $1.0(0.3,4.0)$ & 1.00 & No effect \\
\hline$B L M$ & 35 & 31 & $0.9(0.5,1.4)$ & 0.59 & No effect \\
\hline$C D C 27$ & 12 & 12 & $1.0(0.5,2.3)$ & 0.98 & No effect \\
\hline
\end{tabular}


Table 1 Association of rare coding variants with breast cancer, for the 113 DNA repair genes sequenced in the GENESIS population [20] (Continued)

\begin{tabular}{|c|c|c|c|c|c|}
\hline \multirow[t]{2}{*}{ Gene } & \multicolumn{5}{|l|}{ Any variant } \\
\hline & Control carriers & Case carriers & $\mathrm{OR}^{\mathrm{a}}(95 \% \mathrm{Cl})$ & $P$ value & Group $^{b}$ \\
\hline CDKN2A & 3 & 3 & $1.0(0.2,4.9)$ & 0.99 & No effect \\
\hline EIF4G1 & 26 & 29 & $1.1(0.7,1.9)$ & 0.67 & No effect \\
\hline EP300 & 21 & 18 & $0.9(0.5,1.6)$ & 0.66 & No effect \\
\hline ERCC6 & 47 & 53 & $1.1(0.8,1.7)$ & 0.55 & No effect \\
\hline$F A N C B$ & 9 & 9 & $0.9(0.4,2.4)$ & 0.87 & No effect \\
\hline FANCC & 11 & 10 & $0.9(0.4,2.2)$ & 0.87 & No effect \\
\hline FANCE & 11 & 10 & $0.9(0.4,2.2)$ & 0.86 & No effect \\
\hline FANCL & 9 & 10 & $1.1(0.4,2.8)$ & 0.84 & No effect \\
\hline FLNA & 25 & 24 & $1.0(0.6,1.7)$ & 0.94 & No effect \\
\hline$M A G I 3$ & 26 & 28 & $1.1(0.6,1.8)$ & 0.82 & No effect \\
\hline MAST2 & 46 & 50 & $1.1(0.7,1.7)$ & 0.66 & No effect \\
\hline MCM4 & 25 & 29 & $1.1(0.7,1.9)$ & 0.70 & No effect \\
\hline MCPH1 & 27 & 28 & $1.0(0.6,1.8)$ & 0.92 & No effect \\
\hline$M D C 1$ & 24 & 22 & $0.9(0.5,1.7)$ & 0.81 & No effect \\
\hline MSH2 & 18 & 17 & $0.9(0.5,1.8)$ & 0.76 & No effect \\
\hline MSH6 & 16 & 16 & $0.9(0.5,1.9)$ & 0.86 & No effect \\
\hline$N B N$ & 26 & 27 & $1.0(0.6,1.8)$ & 0.87 & No effect \\
\hline PHLPP2 & 32 & 34 & $1.0(0.6,1.7)$ & 0.97 & No effect \\
\hline POLK & 22 & 22 & $1.0(0.5,1.8)$ & 0.99 & No effect \\
\hline RAD51B/REC2/RAD51L1 & 6 & 5 & $0.9(0.3,2.8)$ & 0.80 & No effect \\
\hline RECQL4 & 49 & 55 & $1.1(0.8,1.7)$ & 0.59 & No effect \\
\hline RINT1 & 8 & 8 & $1.0(0.4,2.8)$ & 0.95 & No effect \\
\hline SETX & 25 & 24 & $1.0(0.6,1.7)$ & 0.91 & No effect \\
\hline TELO2 & 17 & 18 & $1.1(0.5,2.1)$ & 0.89 & No effect \\
\hline$X R C C 2$ & 7 & 6 & $0.9(0.3,2.7)$ & 0.84 & No effect \\
\hline$A P L F$ & 7 & 11 & $1.5(0.6,3.9)$ & 0.40 & High \\
\hline ATM & 40 & 77 & $1.9(1.3,2.9)$ & 0.001 & High \\
\hline BARD1 & 7 & 9 & $1.3(0.5,3.6)$ & 0.59 & High \\
\hline BRIP1/FANCJ & 16 & 25 & $1.5(0.8,2.8)$ & 0.25 & High \\
\hline CHEK1 & 4 & 6 & $1.2(0.3,4.5)$ & 0.75 & High \\
\hline CHEK2 & 22 & 62 & $3.0(1.9,5.0)$ & 0.00001 & High \\
\hline$C H G B$ & 9 & 11 & $1.2(0.5,3.0)$ & 0.65 & High \\
\hline DCLRE1C & 9 & 14 & $1.6(0.7,3.7)$ & 0.28 & High \\
\hline$D G K Z$ & 33 & 38 & $1.2(0.7,1.9)$ & 0.52 & High \\
\hline ERCC2 & 17 & 27 & $1.6(0.9,3.0)$ & 0.13 & High \\
\hline EYA3 & 6 & 7 & $1.2(0.4,3.5)$ & 0.77 & High \\
\hline FANCM & 23 & 38 & $1.7(1.0,2.8)$ & 0.06 & High \\
\hline FEN1 & 6 & 7 & $1.2(0.4,3.6)$ & 0.74 & High \\
\hline FOXO1 & 6 & 7 & $1.8(0.5,6.0)$ & 0.38 & High \\
\hline FOXO3 & 0 & 8 & - & - & High \\
\hline FOXO4 & 0 & 4 & - & - & High \\
\hline MAST1 & 8 & 17 & $2.2(0.9,5.1)$ & 0.07 & High \\
\hline
\end{tabular}


Table 1 Association of rare coding variants with breast cancer, for the 113 DNA repair genes sequenced in the GENESIS population [20] (Continued)

\begin{tabular}{|c|c|c|c|c|c|}
\hline \multirow[t]{2}{*}{ Gene } & \multicolumn{5}{|l|}{ Any variant } \\
\hline & Control carriers & Case carriers & $\mathrm{OR}^{\mathrm{a}}(95 \% \mathrm{Cl})$ & $P$ value & Group $^{b}$ \\
\hline MCM7 & 10 & 18 & $1.8(0.8,4.0)$ & 0.13 & High \\
\hline MLH1 & 15 & 19 & $1.3(0.6,2.5)$ & 0.52 & High \\
\hline MRE11A & 12 & 14 & $1.2(0.6,2.6)$ & 0.64 & High \\
\hline MSH3 & 25 & 30 & $1.2(0.7,2.1)$ & 0.49 & High \\
\hline NTHL1 & 18 & 22 & $1.2(0.6,2.2)$ & 0.65 & High \\
\hline NUMA1 & 36 & 51 & $1.4(0.9,2.2)$ & 0.12 & High \\
\hline PALB2 & 9 & 30 & $3.5(1.7,7.5)$ & 0.001 & High \\
\hline PIK3R1 & 1 & 4 & $4.3(0.5,38.3)$ & 0.20 & High \\
\hline PMS1 & 6 & 10 & $1.5(0.6,4.3)$ & 0.41 & High \\
\hline PPM1D & 4 & 6 & $1.5(0.4,5.4)$ & 0.53 & High \\
\hline PTEN & 0 & 4 & - & - & High \\
\hline RAD50 & 30 & 37 & $1.2(0.7,2.0)$ & 0.44 & High \\
\hline RAD51C & 7 & 10 & $1.5(0.6,4.0)$ & 0.41 & High \\
\hline$R A D 9 B$ & 4 & 6 & $1.5(0.4,5.2)$ & 0.55 & High \\
\hline RECQL5 & 20 & 29 & $1.5(0.9,2.7)$ & 0.14 & High \\
\hline REV3L & 31 & 39 & $1.3(0.8,2.1)$ & 0.30 & High \\
\hline RNF168 & 13 & 16 & $1.2(0.6,2.6)$ & 0.59 & High \\
\hline RPA1 & 9 & 14 & $1.5(0.7,3.6)$ & 0.32 & High \\
\hline SLX4/FANCP & 36 & 44 & $1.2(0.8,1.9)$ & 0.38 & High \\
\hline STK11 & 1 & 2 & $2.1(0.2,22.9)$ & 0.55 & High \\
\hline TGFB 1 & 5 & 9 & $1.6(0.5,4.9)$ & 0.38 & High \\
\hline TOP3A & 22 & 31 & $1.4(0.8,2.5)$ & 0.23 & High \\
\hline TP53 & 3 & 6 & $2.0(0.5,8.0)$ & 0.34 & High \\
\hline TSC2 & 45 & 56 & $1.3(0.9,1.9)$ & 0.23 & High \\
\hline$T T I 1$ & 26 & 30 & $1.2(0.7,2.0)$ & 0.57 & High \\
\hline UIMC1/RAP80 & 12 & 15 & $1.2(0.6,2.7)$ & 0.58 & High \\
\hline USP8 & 9 & 16 & $1.7(0.7,3.8)$ & 0.23 & High \\
\hline WRN & 47 & 59 & $1.3(0.9,1.9)$ & 0.23 & High \\
\hline$X R C C 3$ & 4 & 7 & $1.8(0.5,6.2)$ & 0.36 & High \\
\hline
\end{tabular}

Abbreviations: OR $(95 \% \mathrm{Cl})$ odds ratio (95\% confidence interval)

${ }^{a}$ Reference group: non-carrier of a variant in the tested gene

bGroup "Low": OR <0.9; Group "No Effect": 0.9 OR $\leq 1.1$; Group "High": OR >1.1

adjustment variables were education level (not graduated, basic level, intermediate/high level), birth cohort $(\leq 1945,1946-1959, \geq 1960)$, body mass index at diagnosis for cases, and at interview for controls $(<18.5,18.5-$ $24.99,25-29.99, \geq 30$ ), number of full-term pregnancies (nulliparous, 1-2, $>2)$, age at FFTP $(<20,20-24,25-29$, $\geq 30$ ), mammography exposure at least 1 year before censoring (ever/never), and family history of BC. For this latter variable, the number of first- or second-degree relatives affected with BC was generated. Since cases had an affected sister by design, we excluded one affected sister from the family history count to assess cases' BC family history distribution unbiased by the study design and classified $\mathrm{BC}$ family history as none affected, at least one 1st degree relative affected, or only 2 nd degree relatives affected. We also adjusted for the number of chest $\mathrm{X}$-ray exposures $(\leq 5 \mathrm{vs} .>5)$ when appropriate.

We assessed associations by birth cohort, age at censor, family history of $\mathrm{BC}$, and DNA repair gene group; we used likelihood ratio tests to test for heterogeneity. Additionally, we adjusted for other gene groups when the analysis was stratified by the gene group.

We assessed heterogeneity between estrogen receptor (ER) tumor status using a multinomial logistic regression model and tested equality of coefficients between equations by difference between the log-likelihoods assuming 
a chi-square distribution with 1 degree of freedom (df) for never/ever exposed, $2 \mathrm{df}$ for timing to first full-term pregnancy (FFTP) and age at first exposure, and $3 \mathrm{df}$ for number of exposures.

To minimize potential survival bias, we also conducted an analysis restricted to cases diagnosed at most 5 years before enrollment in GENESIS.

Finally, as the DNA repair gene groups were defined using a priori bounds for ORs, we performed sensitivity analyses using different bounds (i.e., Group "Low": OR< 0.8 or <1.0; Group "No Effect": $0.8 \leq \mathrm{OR} \leq 1.2$ or $\mathrm{OR}=1.0$; Group "High": OR $>1.2$ or $>1.0$ ).

To evaluate the effect of missing information on the observed results, we performed multiple imputations using the chained equations method (MICE) $[21,22]$ as implemented in STATA [23]. This method uses a Gibbs-like algorithm [24] to obtain 100 imputed datasets with complete observations for each outcome. ORs estimated on the imputed data sets were pooled together using Rubin's rules to obtain valid statistical inferences [25].

All $P$ values were two-sided and a $5 \%$ level of significance was used. All analyses were performed using Stata software version 14 [23].

\section{Results}

Characteristics of the study population are described in Table 2. Most of the cases were prevalent with a mean delay between diagnosis and interview of 8.3 years (SD: \pm 7.1). The mean age at $\mathrm{BC}$ diagnosis was 50.2 years (SD: \pm 9.3), and the mean age at interview for the controls was 55.8 years (SD: \pm 9.9 ).

Compared to controls, cases were more likely to have a basic education level, lower BMI, younger age at the FFTP, and as expected, stronger family history of BC. Regarding birth cohort, cases were more likely to be born before 1945 than controls. Among the subset of participants who were sequenced for the 113 DNA repair genes (74.1\%), 20\% of women did not carry any variant and $30.9 \%$ of women carried only one variant. Among those who carried at least two variants, $21.9 \%$ of them carried variants in the same group, and $14.7 \%$ carried variants in genes from all three groups (data not shown). Cases carried variants from Group "High" more often than controls $(57.7 \%$ and $42.6 \%$, respectively) (Table 2).

The distribution of chest X-ray exposures, by type of medical procedure, is shown in Table 3 . When considering conventional radiography plus fluoroscopy, the mean age at first chest X-ray exposure was significantly lower for cases than for controls (20.4 and 22.0 years, respectively; $P=0.003$ ) with a higher percentage of cases exposed before age 20 years than controls $(37.0 \%$ and $31.9 \%$, respectively, $P<10^{-3}$; data not shown).
We found that exposure to chest X-rays was associated with a 2-fold increased odds of $\mathrm{BC}\left(P<10^{-3}\right)$ compared to non-exposed women (Table 4). Each additional procedure was associated with a $3 \%$ increased odds of BC $\left(P<10^{-3}\right)$.

When analyses were performed according to birth cohort, the association between chest X-ray exposure and $\mathrm{BC}$ risk was significant for later birth cohorts, i.e., women born after 1945 (ever vs. never, 1946-1959: OR= $1.65, \geq 1960$ : $\mathrm{OR}=2.54$ ), with a significantly higher risk for women born after $1960\left(P_{\text {het }}=0.024\right)$ (Table 5). We also found significant heterogeneity between birth cohorts for the effect of the number of exposures on $\mathrm{BC}$ risk $\left(P_{\text {het }}=0.041\right)$ with each additional procedure associated with a $6 \%$ increased odds of $\mathrm{BC}\left(P<10^{-3}\right)$ for women born after 1960 . When analyses were performed according to age at censoring and family history of $\mathrm{BC}$ (see Supplemental Tables 2-3 in Additional file 2.doc), none of the heterogeneity tests were significant. However, the effect of chest X-ray exposure was significant only for women over the age of 60 with each additional procedure being associated with a $2 \%$ increased odds $(P=0.036)$.

Interestingly, when stratifying on the gene group, we found that for women carrying at least one variant in Group "High" (i.e., OR>1.1) (see Supplemental Table 4 in Additional file 2.doc), the effect of chest X-ray exposures on $\mathrm{BC}$ risk was significantly higher than for those carrying at least one variant in the other groups $\left(P_{\text {het }}=\right.$ 0.0038) (Table 6) (ever vs. never: Group "Low" (OR<0.9): $\mathrm{OR}=2.02$; Group "No Effect" ${ }_{(0.9 \leq \mathrm{OR} \leq 1.1)}$ : $\mathrm{OR}=1.62$; Group "High" (OR>1.1): OR=3.31). Having had ten or more exposures also doubled the $\mathrm{BC}$ risk for women with a variant from Group "High" (OR>1.1) compared with women in the other two groups $\left(P_{\text {het }}=0.022\right)$.

When considering chest X-ray exposure (ever vs. never) and number of variants simultaneously, BC risk increased with increasing number of variants from Group "High" (OR>1.1) with a significant 66\% increased odds of $\mathrm{BC}$ for each additional variant. Inversely, $\mathrm{BC}$ risk decreased with increasing number of variants from Group "Low" (OR<0.9) with a significant 31\% decreased odds of $\mathrm{BC}$ for each additional variant (Table 7).

When analyses were performed according to tumor ER status (Table 8), the heterogeneity tests were not significant when we compared ORs between ER- and ER+ tumors for any chest X-ray exposure variables, although there was a suggestive stronger association in the ever vs. never analysis for women with ER+ tumors when compared to women with ER- tumors.

In all analyses (Tables 4, 5, 6, and 8), there was no significant difference in the $\mathrm{BC}$ risk by age at first exposure, nor by timing according to the FFTP.

Because some chest X-ray variables had a high fraction of missing data, we reran the above analyses after 
Table 2 Characteristics of GENESIS participants

\begin{tabular}{|c|c|c|c|c|}
\hline \multirow[t]{2}{*}{ Characteristics } & \multicolumn{2}{|c|}{$\begin{array}{l}\text { Cases } \\
N=1,552\end{array}$} & \multicolumn{2}{|c|}{$\begin{array}{l}\text { Controls } \\
N=1,363\end{array}$} \\
\hline & No. & $\overline{\%}$ & No. & $\%$ \\
\hline \multicolumn{5}{|l|}{ Birth cohort } \\
\hline$\leq 1945$ & 488 & 31.4 & 294 & 21.6 \\
\hline $1946-59$ & 797 & 51.4 & 706 & 51.8 \\
\hline$\geq 1960$ & 267 & 17.2 & 363 & 26.6 \\
\hline \multicolumn{5}{|c|}{ Age at censoring, years } \\
\hline Mean (sd) & $50.2(9.3)$ & & $55.8(9.9)$ & \\
\hline$\leq 45$ & 513 & 33.1 & 201 & 14.8 \\
\hline $46-50$ & 336 & 21.7 & 197 & 14.5 \\
\hline $51-60$ & 473 & 30.5 & 485 & 35.6 \\
\hline$>60$ & 230 & 14.8 & 480 & 35.2 \\
\hline
\end{tabular}

\section{Education level}

Intermediate/high

Basic

Not graduated

Missing

Body mass index

$18.5-24.9$

$<18.5$

$\geq 25$ and $<30$

$\geq 30$

Missing

Smoking

No

Current

Past

Missing

Number of full term pregnancies

$\geq 2$

$1-2$

0

Missing

Age at first full-term pregnancy, years

$<20$

20-24

25-29

$\geq 30$

No full-term pregnancy

Missing

Family history of breast cancer ${ }^{a}$

None

1st degree

Only 2nd degree
780

714

58

0

1,019

69

341

120

3

832

159

550

11

445

921

185

1

179

628

393

165

185

2

427

818

307
50.3

46.0

3.7

0.0

65.6

4.5

22.0

7.7

0.2

53.6

10.2

35.4

0.7

28.7

59.3

11.9

0.1

11.5

40.5

25.4

10.6

11.9

0.1

27.5

52.7

19.8
14.8

14.5

35.6

35.2

67.2

31.8

0.9

0.1

63.8

2.3

25.3

8.6

0.0

49.9

11.6

37.7

0.8

30.2

56.0

13.7

0.1

7.5

39.0

28.8

10.9

13.7

0.1

70.4

13.7

15.9 
Table 2 Characteristics of GENESIS participants (Continued)

\begin{tabular}{|c|c|c|c|c|}
\hline \multirow[t]{2}{*}{ Characteristics } & \multicolumn{2}{|c|}{$\begin{array}{l}\text { Cases } \\
N=1,552\end{array}$} & \multicolumn{2}{|c|}{$\begin{array}{l}\text { Controls } \\
N=1,363\end{array}$} \\
\hline & No. & $\overline{\%}$ & No. & $\%$ \\
\hline Missing & 0 & 0.0 & 1 & 0.1 \\
\hline \multicolumn{5}{|c|}{ Tumor estrogen receptors (ER) } \\
\hline ER+ & 818 & 52.7 & & \\
\hline ER- & 168 & 10.8 & & \\
\hline Missing & 566 & 36.5 & & \\
\hline \multicolumn{5}{|l|}{ Gene group ${ }^{\mathbf{b}}$} \\
\hline \multicolumn{5}{|l|}{ Group "Low" } \\
\hline 0 & 723 & 46.6 & 721 & 52.9 \\
\hline$\geq 1$ & 274 & 17.7 & 441 & 32.4 \\
\hline \multicolumn{5}{|l|}{ Group "No Effect" } \\
\hline 0 & 575 & 37.1 & 659 & 48.4 \\
\hline$\geq 1$ & 422 & 27.2 & 503 & 36.9 \\
\hline \multicolumn{5}{|l|}{ Group "High" } \\
\hline 0 & 422 & 27.2 & 667 & 48.9 \\
\hline$\geq 1$ & 575 & 37.1 & 495 & 36.3 \\
\hline Missing & 555 & 35.8 & 201 & 14.8 \\
\hline
\end{tabular}

aEcluding one affected sister per index case, "none" means no history of BC for controls or no additional BC case in the family for cases; "1st degree" means 1st degree family history for controls or additional 1st degree relative for cases and "2nd degree" means only 2nd degree family history for controls or only additional 2nd degree family history for cases

bIndividuals carrying at least one variant in one of the Gene Groups: Group "Low" (OR<0.9); Group "No Effect" (0.9 $\leq \mathrm{OR} \leq 1.1)$; Group "High" (OR>1.1)

imputing the missing data (Tables 4 and 7; Supplemental Tables 4-10 in Additional file 2.doc). The magnitude and direction of the effect estimates based on analyses using an extra class for missing data or a multiple imputation strategy were similar.

We also performed analyses restricted to cases diagnosed at most 5 years before enrollment in the study. Again, the magnitude and direction of the effect estimates were unchanged (see Supplemental Table 10 in Additional file 2.doc).

\section{Discussion}

We found that chest X-ray exposure doubles the risk of $\mathrm{BC}$ in women with a hereditary predisposition to $\mathrm{BC}$ unexplained by a $B R C A 1 / 2$ mutation. This risk increases with the number of exposures with an increase of $3 \%$ for each additional exposure. Being born after 1960, over age 60 or a carrier of at least one variant in the DNA repair genes group associated with an increased risk of $\mathrm{BC}$ increased the effect of chest X-ray exposure on $\mathrm{BC}$ risk.

Our study confirms that low-dose ionizing radiation to the thoracic region increases the risk of $\mathrm{BC}$ among highrisk women, as pointed out by other studies $[1,7,8,18]$. In contrast to Ma et al. [6] and John et al. [11], we did not find that younger age at first chest $\mathrm{X}$-ray exposure was significantly associated with higher ORs compared to those initially exposed at an older age. However, we found a suggestive association between having been exposed at an early age in the subgroup of women born between 1946 and 1959 or those older than 50 years at censoring and in the subgroup of women without a family history of $\mathrm{BC}$ (i.e., only one sister affected for cases and none for controls) but due to the self-report exposures and potential recall bias, these results should be taken with cautious.

We also observed a difference by birth cohort on radiation-induced risk of $\mathrm{BC}$, with significantly higher risks for women born after 1960, which was similar to $\mathrm{BC}$ risk in women carrying a $B R C A 1 / 2$ pathogenic variant and born after 1950 [3]. However, this finding was not subsequently confirmed in the Pijpe et al. study [5]. Even if radiation exposure levels were higher in the past, the decrease over the generations in the number of exposed subjects by outcome status appeared different, especially in the younger birth cohort. This may be due to the reluctance of doctors to reduce radiological examinations in women at high risk of cancer, more often classified accordingly since the discovery of the first BC predisposing genes in the 1990s [26, 27].

When stratifying on tumor ER status, we found a suggestive stronger effect of chest X-ray exposure for women with an $\mathrm{ER}^{+}$tumor, consistent with Sigurdson 
Table 3 Chest diagnostic/screening X-ray exposure characteristics by medical procedures

\begin{tabular}{|c|c|c|c|c|}
\hline \multirow[t]{2}{*}{ Characteristics $^{\mathrm{a}}$} & \multicolumn{2}{|l|}{$\begin{array}{l}\text { Cases } \\
N=1552\end{array}$} & \multicolumn{2}{|l|}{$\begin{array}{l}\text { Controls } \\
N=1363\end{array}$} \\
\hline & No. & $\%$ & No. & $\%$ \\
\hline \multicolumn{5}{|c|}{ Conventional radiography + fluoroscopy } \\
\hline Never & 213 & 13.7 & 242 & 17.8 \\
\hline Ever & 1,296 & 83.5 & 1,097 & 80.5 \\
\hline Missing & 43 & 2.8 & 24 & 1.8 \\
\hline \multicolumn{5}{|c|}{ Number of lifetime exposures } \\
\hline $1-3$ & 377 & 24.3 & 379 & 27.8 \\
\hline $4-9$ & 248 & 16.0 & 195 & 14.3 \\
\hline$\geq 10$ & 258 & 16.6 & 213 & 15.6 \\
\hline Missing & 456 & 29.4 & 334 & 24.5 \\
\hline \multicolumn{5}{|c|}{ Age at first exposure (years) } \\
\hline Mean (sd) & $20.4(10.9)$ & & $22.0(12.5)$ & \\
\hline Missing & 291 & 18.8 & 202 & 14.8 \\
\hline \multicolumn{5}{|l|}{ Tomography } \\
\hline Never & 1,389 & 89.5 & 1,276 & 93.6 \\
\hline Ever & 48 & 3.1 & 40 & 2.9 \\
\hline Missing & 115 & 7.4 & 47 & 3.5 \\
\hline \multicolumn{5}{|c|}{ Number of lifetime exposures } \\
\hline 1 & 37 & 2.4 & 30 & 2.2 \\
\hline$\geq 2$ & 9 & 0.6 & 9 & 0.7 \\
\hline Missing & 117 & 7.5 & 48 & 3.5 \\
\hline \multicolumn{5}{|c|}{ Age at first exposure (years) } \\
\hline Mean (sd) & $40.0(15.8)$ & & $42.8(15.4)$ & \\
\hline Missing & 115 & 7.4 & 47 & 3.5 \\
\hline \multicolumn{5}{|l|}{ Scintigraphy } \\
\hline Never & 1,416 & 91.2 & 1,294 & 94.9 \\
\hline Ever & 21 & 1.4 & 22 & 1.6 \\
\hline Missing & 115 & 7.4 & 47 & 3.5 \\
\hline \multicolumn{5}{|c|}{ Number of lifetime exposures } \\
\hline 1 & 18 & 1.2 & 18 & 1.3 \\
\hline$\geq 2$ & 3 & 0.2 & 4 & 0.3 \\
\hline Missing & 115 & 7.4 & 47 & 3.5 \\
\hline \multicolumn{5}{|c|}{ Age at first exposure (years) } \\
\hline Mean $(s d)$ & $50.8(10.2)$ & & $53.4(12.0)$ & \\
\hline Missing & 115 & 7.4 & 47 & 3.5 \\
\hline \multicolumn{5}{|l|}{ Mammography } \\
\hline Never & 266 & 17.1 & 102 & 7.5 \\
\hline Ever & 1271 & 81.9 & 1252 & 91.9 \\
\hline Missing & 15 & 1.0 & 9 & 0.7 \\
\hline
\end{tabular}

${ }^{\mathrm{a}}$ Lifetime exposures up to one year prior to diagnosis for cases and up to one year prior to date of questionnaire completion for controls

et al.'s findings that common variants in estrogen metabolizing genes may modify the association between ionizing radiation exposure and $\mathrm{BC}$ risk [28].
Several strengths and weaknesses should be considered in the interpretation of our results. First, we did not include mammography in the chest X-ray exposure 
Table 4 Effect of lifetime chest X-ray exposure (any exposure) on breast cancer risk according to the number of exposures, the age at first exposure, and the first full-term pregnancy

\begin{tabular}{|c|c|c|c|c|c|c|}
\hline & \multicolumn{2}{|c|}{ Number of } & \multirow[b]{2}{*}{$O R^{a}$} & \multirow[b]{2}{*}{$95 \% \mathrm{Cl}$} & \multicolumn{2}{|c|}{ Multiple Imputation } \\
\hline & Cases & $\overline{\text { Controls }}$ & & & $\mathrm{OR}^{\mathrm{a}}$ & $95 \% \mathrm{Cl}$ \\
\hline \multicolumn{7}{|l|}{ Chest X-ray exposure $^{b}$} \\
\hline Never & 208 & 239 & 1 & & 1 & \\
\hline Ever & 1304 & 1104 & 2.05 & $1.55-2.73$ & 2.05 & $1.54-2.72$ \\
\hline \multicolumn{7}{|l|}{ Number of exposures } \\
\hline 0 & 208 & 239 & 1 & & 1 & \\
\hline $1-3$ & 392 & 390 & 1.70 & $1.23-2.34$ & 1.62 & $1.18-2.23$ \\
\hline $4-9$ & 251 & 200 & 2.52 & $1.76-3.61$ & 2.29 & $1.65-3.16$ \\
\hline$\geq 10$ & 263 & 215 & 2.37 & $1.64-3.43$ & 2.70 & $1.89-3.87$ \\
\hline Continuous & & & 1.03 & $1.01-1.04$ & 1.03 & $1.02-1.05$ \\
\hline \multicolumn{7}{|l|}{ Age at first exposure, years ${ }^{c}$} \\
\hline No exposure & 208 & 239 & 0.55 & $0.40-0.76$ & 0.58 & $0.42-0.80$ \\
\hline$\geq 20$ & 485 & 490 & 1 & & 1 & \\
\hline $15-19$ & 288 & 222 & 1.02 & $0.75-1.37$ & 1.01 & $0.75-1.36$ \\
\hline$<15$ & 290 & 219 & 1.11 & $0.83-1.50$ & 1.08 & $0.80-1.45$ \\
\hline Continuous & & & 1.00 & $0.99-1.01$ & 1.01 & $0.99-1.02$ \\
\hline \multicolumn{7}{|c|}{ According to first full-term pregnancy (FFTP) ${ }^{c}$} \\
\hline Only after FFTPd & 268 & 232 & 1 & & 1 & \\
\hline Before (incl. no FTP) & 825 & 725 & 0.81 & $0.61-1.08$ & 0.85 & $0.64-1.12$ \\
\hline \multicolumn{7}{|c|}{ According to first FFTP and number of exposures } \\
\hline Only after and $\leq 5^{d}$ & 186 & 178 & 1 & & 1 & \\
\hline Only after and $>5^{d}$ & 56 & 43 & 1.77 & $0.98-3.18$ & 1.68 & $0.99-2.85$ \\
\hline Before and $\leq 5$ (incl. no FTP) & 442 & 412 & 0.95 & $0.67-1.36$ & 0.89 & $0.63-1.25$ \\
\hline Before and >5 (incl. no FTP) & 272 & 215 & 1.12 & $0.77-1.61$ & 1.33 & $0.96-1.85$ \\
\hline
\end{tabular}

Abbreviations: OR $(95 \% \mathrm{Cl})$ odds ratio (95\% confidence interval)

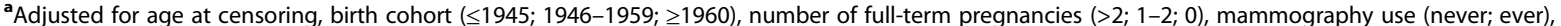

educational level (intermediate/high; basic; not graduated), BMI (18.5-24.9; $<18.5 ; \geq 25$ and $<30 ; \geq 30$ ), smoking (no; current; past), and breast cancer family history (0;1st degree; 2nd degree)

${ }^{\mathrm{b}}$ Chest X-ray exposure includes pulmonary radiological examinations in the field of preventive/occupational medicine or for lung disease, preoperative radiological examinations, and radiological examinations of heart and thoracic vessels for all the reported procedures

${ }^{\mathrm{C}}$ Adjusted as in ${ }^{\mathrm{a}}$ plus number of exposures $(\leq 5 ;>5)$

${ }^{\mathrm{d}}$ After $=$ also includes chest X-ray exposure that occurred during the same year of first full-term pregnancy

because we were concerned about confounding by indication, i.e., self-selection for early mammography in women with a strong family history of BC. However, all analyses were adjusted for mammography to avoid confounding. Confounding by indication for other diagnostic procedures is expected to be highly unlikely.

Potential weaknesses also include the fact that most of the cases were prevalent cases which could lead to estimates biased toward the null if radiation exposure was associated with poorer survival. Unfortunately, very little is known about the influence of exposure to ionizing radiation at any doses on overall survival and $\mathrm{BC}$ specific survival in high-risk BC families. Nevertheless, we performed sensitivity analyses on a subgroup of cases diagnosed within 5 years before enrollment in the study and results remained unchanged. Another potential weakness is the selection of nonrandom friends or colleagues as controls. The advantage of such controls was the greater feasibility for finding a suitable control than through a random selection in the general population, and a higher comparability for unmeasured factors with, however, the risk of sharing some risk factors with the index cases. However, friends or colleagues' selection should not have X-ray radiation exposures related to friend or colleague relationships, and if any, $\mathrm{BC}$ relative risks associated with $\mathrm{X}$-ray exposures would be expected to be biased towards the null. Finally, information on lifetime X-ray exposures was self-reported with accompanying potential recall biases and exposure misclassification. 


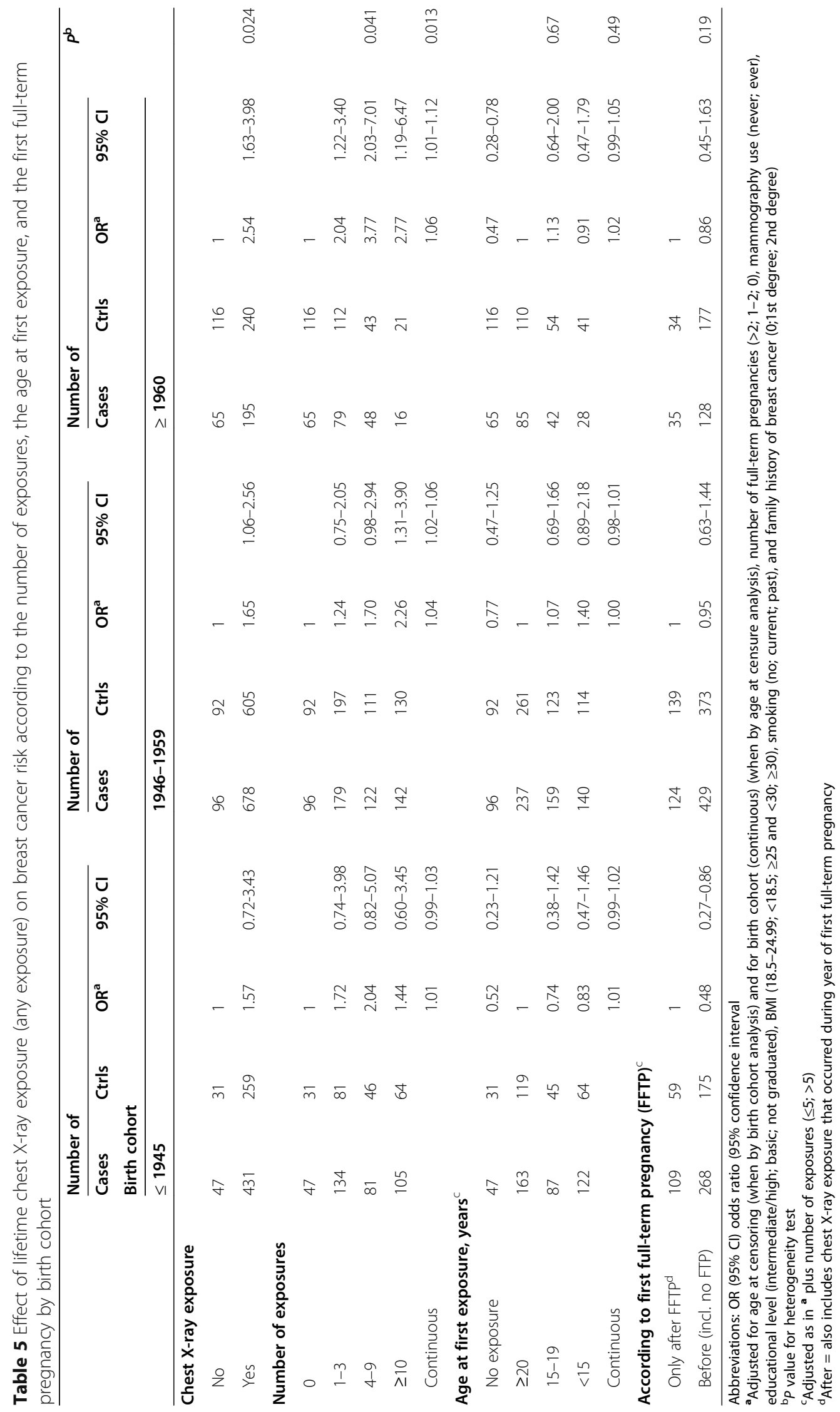




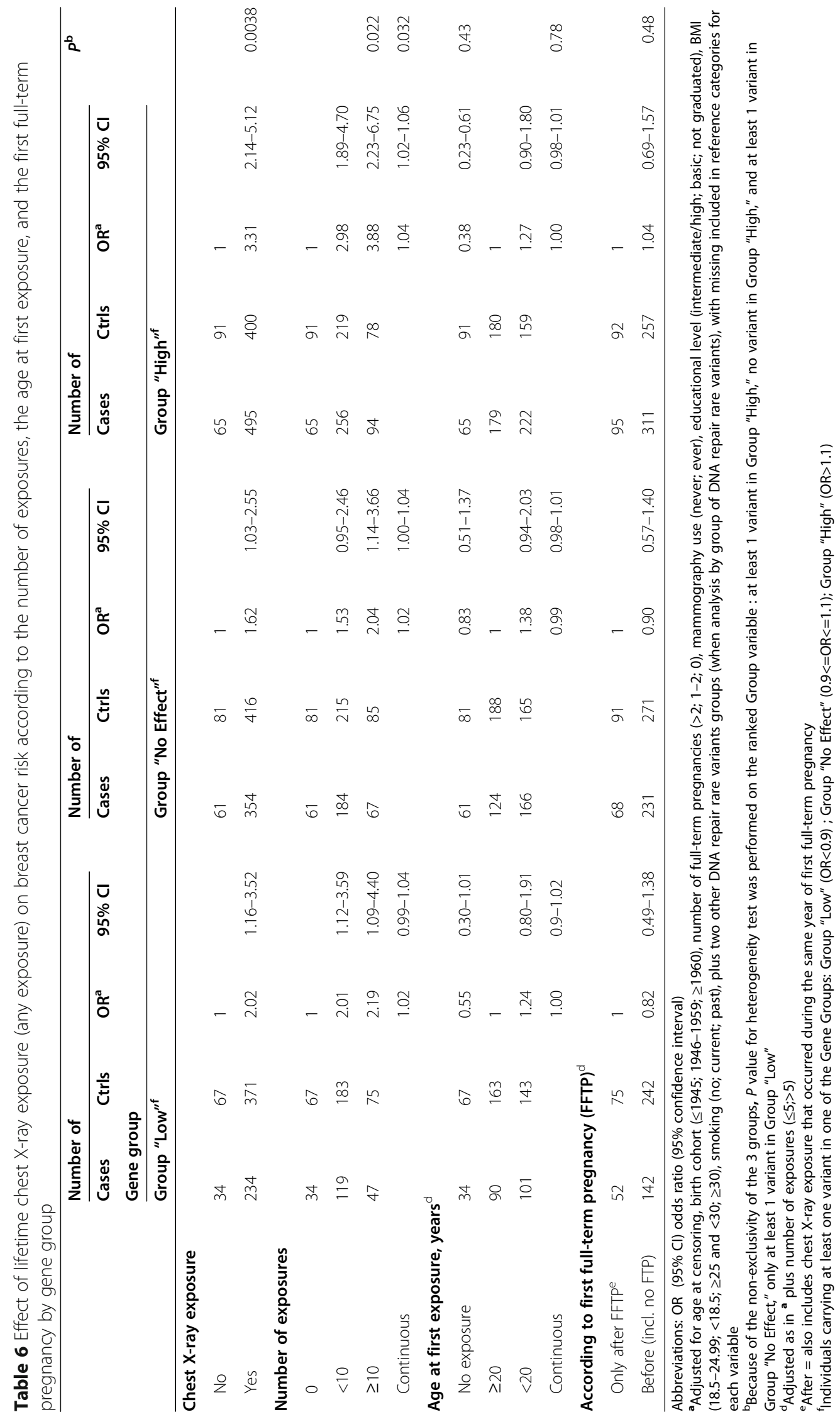


Table 7 Combined effect of chest $X$-ray exposure and genetic variants

\begin{tabular}{|c|c|c|c|c|c|c|}
\hline \multirow{2}{*}{$\begin{array}{l}\text { Chest X-ray } \\
\text { exposure } \& \text { number } \\
\text { of DNA repair rare } \\
\text { variants }\end{array}$} & \multicolumn{2}{|c|}{ Number of } & \multirow[b]{2}{*}{$O R^{a}$} & \multirow[b]{2}{*}{$95 \% \mathrm{Cl}$} & \multicolumn{2}{|c|}{ Multiple imputation } \\
\hline & Cases & $\overline{\text { Ctrls }}$ & & & $\overline{\mathrm{OR}^{\mathrm{a}}}$ & $95 \% \mathrm{Cl}$ \\
\hline \multicolumn{7}{|l|}{ Group ‘Low'b } \\
\hline Ever \& 0 variant & 604 & 580 & 1 & & 1 & \\
\hline Ever \& 1 variant & 197 & 288 & 0.67 & $0.52-0.86$ & 0.67 & $0.52-0.87$ \\
\hline Ever $\& 2$ variants & 34 & 69 & 0.52 & $0.32-0.84$ & 0.49 & $0.30-0.79$ \\
\hline Ever $\& \geq 3$ variants & 3 & 14 & 0.25 & $0.06-1.00$ & 0.25 & $0.06-0.99$ \\
\hline Never & 135 & 195 & 0.50 & $0.37-0.68$ & 0.31 & $0.18-0.52$ \\
\hline Continuous $^{\mathrm{e}}$ & & & 0.69 & $0.57-0.84$ & 0.69 & $0.58-0.83$ \\
\hline Never \& 0 variant & 101 & 128 & 1 & & 1 & \\
\hline Never \& 1 variant & 27 & 50 & 0.56 & $0.30-1.06$ & 0.56 & $0.30-1.05$ \\
\hline Never \& 2 variants & 7 & 16 & 0.52 & $0.17-1.57$ & 0.48 & $0.16-1.44$ \\
\hline Never $\& \geq 3$ variants & 0 & 1 & - & & - & \\
\hline Ever \& 0 variant & 604 & 580 & 1.67 & $1.19-2.34$ & 1.66 & $1.18-2.34$ \\
\hline Ever \& 1 variant & 197 & 288 & 1.12 & $0.77-1.62$ & 1.12 & $0.77-1.64$ \\
\hline Ever $\& 2$ variants & 34 & 69 & 0.86 & $0.50-1.51$ & 0.82 & $0.46-1.43$ \\
\hline Ever $\& \geq 3$ variants & 3 & 14 & 0.42 & $0.10-1.71$ & 0.42 & $0.10-1.71$ \\
\hline \multicolumn{7}{|l|}{ Group 'No Effect' } \\
\hline Ever \& 0 variant & 484 & 535 & 1 & & 1 & \\
\hline Ever \& 1 variant & 258 & 318 & 0.96 & $0.76-1.22$ & 0.97 & $0.76-1.23$ \\
\hline Ever $\& 2$ variants & 81 & 78 & 1.12 & $0.76-1.65$ & 1.15 & $0.77-1.70$ \\
\hline Ever $\& \geq 3$ variants & 15 & 20 & 1.21 & $0.55-2.70$ & 1.28 & $0.57-2.87$ \\
\hline Never & 135 & 195 & 0.58 & $0.43-0.78$ & 0.61 & $0.40-0.94$ \\
\hline Continuous $^{e}$ & & & 1.02 & $0.86-1.21$ & 1.05 & $0.90-1.21$ \\
\hline Never \& 0 variant & 74 & 114 & 1 & & 1 & \\
\hline Never \& 1 variant & 45 & 67 & 1.08 & $0.62-1.90$ & 1.08 & $0.61-1.89$ \\
\hline Never \& 2 variants & 14 & 12 & 1.40 & $0.55-3.59$ & 1.50 & $0.59-3.84$ \\
\hline Never $\& \geq 3$ variants & 2 & 2 & 1.90 & $0.23-15.8$ & 1.93 & $0.23-16.1$ \\
\hline Ever \& 0 variant & 484 & 535 & 1.85 & $1.27-2.70$ & 1.85 & $1.27-2.71$ \\
\hline Ever \& 1 variant & 258 & 318 & 1.77 & $1.19-2.65$ & 1.78 & $1.19-2.66$ \\
\hline Ever $\& 2$ variants & 81 & 78 & 2.07 & $1.25-3.42$ & 2.13 & $1.29-3.54$ \\
\hline Ever $\& \geq 3$ variants & 15 & 20 & 2.24 & $0.95-5.32$ & 2.39 & $1.01-5.64$ \\
\hline \multicolumn{7}{|l|}{ Group 'High'd } \\
\hline Ever \& 0 variant & 343 & 551 & 1 & & 1 & \\
\hline Ever \& 1 variant & 327 & 291 & 2.06 & $1.62-2.63$ & 2.07 & $1.62-2.65$ \\
\hline Ever $\& 2$ variants & 122 & 93 & 2.34 & $1.66-3.31$ & 2.28 & $1.60-3.23$ \\
\hline Ever $\& \geq 3$ variants & 46 & 16 & 4.61 & $2.34-9.08$ & 4.65 & $2.35-9.22$ \\
\hline Never & 135 & 195 & 0.85 & $0.63-1.16$ & 0.74 & $0.49-1.13$ \\
\hline Continuous $^{\mathrm{e}}$ & & & 1.67 & $1.42-1.96$ & 1.66 & $1.44-1.90$ \\
\hline Never \& 0 variant & 70 & 104 & 1 & & 1 & \\
\hline Never \& 1 variant & 46 & 62 & 0.90 & $0.51-1.58$ & 0.88 & $0.50-1.54$ \\
\hline Never \& 2 variants & 13 & 23 & 0.66 & $0.27-1.57$ & 0.58 & $0.24-1.41$ \\
\hline Never $\& \geq 3$ variants & 6 & 6 & 2.01 & $0.54-7.48$ & 2.01 & $0.54-7.45$ \\
\hline Ever \& 0 variant & 343 & 551 & 1.12 & $0.75-1.65$ & 1.10 & $0.75-1.63$ \\
\hline
\end{tabular}


Table 7 Combined effect of chest $X$-ray exposure and genetic variants (Continued)

\begin{tabular}{|c|c|c|c|c|c|c|}
\hline \multirow{2}{*}{$\begin{array}{l}\text { Chest X-ray } \\
\text { exposure \& number } \\
\text { of DNA repair rare } \\
\text { variants }\end{array}$} & \multicolumn{2}{|c|}{ Number of } & \multirow[b]{2}{*}{$O R^{a}$} & \multirow[b]{2}{*}{$95 \% \mathrm{Cl}$} & \multicolumn{2}{|c|}{ Multiple imputation } \\
\hline & Cases & Ctrls & & & $\mathrm{OR}^{\mathrm{a}}$ & $95 \% \mathrm{Cl}$ \\
\hline Ever \& 1 variant & 327 & 291 & 2.30 & $1.54-3.44$ & 2.28 & $1.53-3.40$ \\
\hline Ever $\& 2$ variants & 122 & 93 & 2.61 & $1.63-4.19$ & 2.51 & $1.56-4.03$ \\
\hline Ever $\& \geq 3$ variants & 46 & 16 & 5.15 & $2.43-10.9$ & 5.10 & $2.41-10.8$ \\
\hline
\end{tabular}

Abbreviations: OR (95\%Cl) odds ratio (95\% confidence interval)

${ }^{a}$ Adjusted for age at censoring, birth cohort ( $\left.\leq 1945 ; 1946-1959 ; \geq 1960\right)$, number of full-term pregnancies ( $\left.>2 ; 1-2 ; 0\right)$, mammography use (never; ever), educational level (intermediate/high; basic; not graduated), BMI $(18.5-24.99 ;<18.5 ; \geq 25$ and $<30 ; \geq 30)$, smoking (no; current; past), and two other DNA repair genes groups bat least one variant in a gene from Group 'Low'

'at least one variant in a gene from Group 'No Effect'

dat least one variant in a gene from Group 'High'

e"Never" excluded

We relied on self-reports rather than review of medical records because of the difficulties in accessing medical records for the various diagnostic procedures. Even if methodological studies showed that the extent of misclassification was small and mainly non-differential by disease status $[29,30]$, an indication of relatively poorer reporting among controls, particularly for certain types of X-ray examinations and for large numbers of such examinations, was shown by Berrington et al., although it did not translate into large differences in the estimated risks [31]. Therefore, we cannot totally rule out such a

Table 8 Effect of lifetime chest X-ray exposure (any exposure) on breast cancer risk according to the number of exposures, the age at first exposure, and the first full-term pregnancy by estrogen receptor tumor status

\begin{tabular}{|c|c|c|c|c|c|c|c|c|c|c|c|}
\hline & \multicolumn{11}{|c|}{ Estrogen receptor (ER) tumor status } \\
\hline & \multicolumn{4}{|c|}{ ER negative } & \multicolumn{3}{|c|}{ ER positive } & \multirow[b]{2}{*}{$P^{\mathbf{b}}$} & \multicolumn{3}{|c|}{ Unknown } \\
\hline & Controls & Cases & $\mathrm{OR}^{\mathrm{a}}$ & $95 \% \mathrm{Cl}$ & Cases & $\mathrm{OR}^{\mathrm{a}}$ & $95 \% \mathrm{Cl}$ & & Cases & $\mathrm{OR}^{\mathrm{a}}$ & $95 \% \mathrm{Cl}$ \\
\hline \multicolumn{12}{|l|}{ Chest X-ray exposure } \\
\hline No & 239 & 32 & 1 & & 107 & 1 & & & 69 & 1 & \\
\hline Yes & 1104 & 132 & 1.50 & $0.94-2.39$ & 692 & 2.13 & $1.56-2.91$ & 0.16 & 480 & 2.21 & $1.51-3.24$ \\
\hline \multicolumn{12}{|l|}{ Number of exposures } \\
\hline 0 & 239 & 32 & 1 & & 107 & 1 & & & 69 & 1 & \\
\hline $1-3$ & 390 & 43 & 1.31 & $0.77-2.25$ & 207 & 1.73 & $1.22-2.46$ & 0.67 & 142 & 1.87 & $1.21-2.87$ \\
\hline $4-9$ & 200 & 29 & 1.99 & $1.10-3.62$ & 140 & 2.65 & $1.80-3.92$ & & 82 & 2.51 & $1.55-4.07$ \\
\hline$\geq 10$ & 215 & 21 & 1.51 & $0.79-2.90$ & 124 & 2.23 & $1.49-3.33$ & & 118 & 3.27 & $2.03-5.28$ \\
\hline Continuous & & & 1.01 & $0.99-1.04$ & & 1.02 & $1.00-1.03$ & 0.58 & & 1.03 & $1.01-1.05$ \\
\hline \multicolumn{12}{|c|}{ Age at first exposure, years ${ }^{c}$} \\
\hline No exposure & 239 & 32 & 0.70 & $0.41-1.19$ & 107 & 0.53 & $0.38-0.75$ & & 69 & 0.53 & $0.35-0.81$ \\
\hline$\geq 20$ & 490 & 52 & 1 & & 263 & 1 & & & 170 & 1 & \\
\hline $15-19$ & 222 & 33 & 1.06 & $0.64-1.78$ & 154 & 1.07 & $0.78-1.47$ & 0.66 & 101 & 0.86 & $0.58-1.27$ \\
\hline$<15$ & 219 & 27 & 1.13 & $0.66-1.94$ & 139 & 1.04 & $0.75-1.44$ & & 124 & 1.25 & $0.86-1.82$ \\
\hline Continuous & & & 1.01 & $0.99-1.03$ & & 1.01 & $0.99-1.02$ & 0.39 & & 1.00 & $0.99-1.01$ \\
\hline \multicolumn{12}{|c|}{ According to first full-term pregnancy (FFTP) ${ }^{c}$} \\
\hline Only after FFTPd & 232 & 35 & 1 & & 141 & 1 & & & 92 & 1 & \\
\hline Before (incl. no FTP) & 725 & 79 & 0.66 & $0.41-1.07$ & 435 & 0.83 & $0.61-1.13$ & 0.22 & 311 & 0.84 & $0.58-1.22$ \\
\hline
\end{tabular}

Abbreviations: OR $(95 \% \mathrm{Cl})$ odds ratio $(95 \%$ confidence interval)

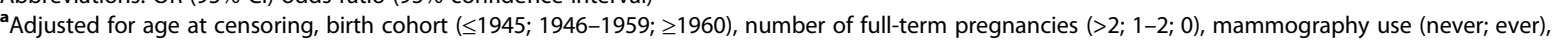

educational level (intermediate/high; basic; not graduated), BMI (18.5-24.99; <18.5; $\geq 25$ and $<30 ; \geq 30)$, smoking (no; current; past), and breast cancer family history (0;1st degree; 2 nd degree)

${ }^{\mathrm{b}} P$ value for $X^{2}$ heterogeneity test between ER-negative and ER-positive tumors

${ }^{c}$ Adjusted as in ${ }^{\text {a }}$ plus number of exposures $(\leq 5 ;>5)$

${ }^{\mathrm{d}}$ After $=$ also includes chest X-ray exposure that occurred during the same year of first full-term pregnancy 
bias, and results on number of exposures and age at exposures should be interpreted with caution.

One important strength of our study is that it was conducted in a homogeneous sample of high-risk women and population controls with detailed information on diagnostic procedures at different age periods. We also dealt with missing values by performing multiple imputation, which showed results with similar magnitudes and direction of effects.

Another strength was the availability of sequencing data for 113 DNA repair genes for an important subset of the study population [20]. Indeed, our study is the first to investigate the joint effect of chest X-ray exposure and rare deleterious or likely deleterious variants in DNA repair genes in women at high risk of BC. Nevertheless, we cannot exclude potential biases due to the classification of the genes according to the ORs calculated in the same population.

Moreover, we fixed a large range of ORs around 1 for the group of DNA repair genes defined as conferring no effect on $\mathrm{BC}$ and this might have an impact on the findings. Therefore, sensitivity analyses were performed changing the boundaries and we found similar trends in the difference in the BC risk between groups (Supplemental Table 11). We also performed a sensitivity analysis that excluded from the "High" Group the genes that were significantly (or borderline) associated with $\mathrm{BC}$ in our population (i.e., ATM, CHEK2, PALB2, FANCM, MAST1) to test whether the differential effect was driven by those genes. Again, results were unchanged (Supplemental Table 12. This analysis also pointed out, for the first time, that carriers of a rare variant in the wellestablished BC susceptibility genes ATM, CHEK2, or PALB2 may be more radiosensitive than non-carriers.

Unlike previous reports, we did not find that the effect of chest X-ray exposure on BC risk was modified by family history $[7,9,32]$. This may be due to greater homogeneity in $\mathrm{BC}$ family history of the current sample compared with the previous studies.

\section{Conclusions}

Our results showed that chest X-ray exposure increases $\mathrm{BC}$ risk 2-fold and suggested that, independent of family history, carrying rare deleterious or likely deleterious variant(s) in some DNA repair genes may modify the effect of chest X-ray exposure. Further studies are needed to evaluate other DNA repair genes or variants to identify those which could increase radiation sensitivity. Identification of sub-populations that are more or less susceptible to ionizing radiation is important and clinically relevant.

\section{Abbreviations}

BC: Breast cancer; DNA: Deoxyribonucleic acid; OR: Odds ratio; Cl: Confidence interval; FFTP: First full-term pregnancy; BRCA1/2: BRCA1 or BRCA2

\section{Supplementary Information}

The online version contains supplementary material available at https://doi. org/10.1186/s13058-021-01456-1. Additional file 1. doc includes 'Supplementary Method Section' on the
eligibility criteria for admission of BC patients to family cancer clinics and DNA repair-related variants identification.

Additional file 2: doc includes 'Supplementary tables'. Supplemental Table 1. Comparison of the distribution of the characteristics between the subset of cases and controls with and without sequenced genes.

Supplemental Table 2. Effect of lifetime chest X-ray exposure (any exposure) on breast cancer risk according to the number of exposures, the age at first exposure and the first full-term pregnancy by age at censor. Supplemental Table 3. Effect of lifetime chest X-ray exposure (any exposure) on breast cancer risk according to the number of exposures, the age at first exposure and the first full-term pregnancy by family history of breast cancer. Supplemental Table 4. Effect of variant carrier status on breast cancer in the GENESIS population. Supplemental Table 5. Effect of lifetime chest $X$-ray exposure (any exposure) on breast cancer risk according to the number of exposures, the age at first exposure and the first full-term pregnancy by birth cohort, after imputation of missing data. Supplemental Table 6. Effect of lifetime chest X-ray exposure (any exposure) on breast cancer risk according to the number of exposures, the age at first exposure and the first full-term pregnancy by age at censoring, after imputation of missing data. Supplemental Table 7. Effect of lifetime chest $X$-ray exposure (any exposure) on breast cancer risk according to the number of exposures, the age at first exposure and the first full-term pregnancy by family history of breast cancer and by variant carrier status, after imputation of missing data. Supplemental Table 8. Effect of lifetime chest $X$-ray exposure (any exposure) on breast cancer risk according to the number of exposures, the age at first exposure and the first full-term pregnancy stratified by variant carrier status, after imputation of missing data. Supplemental Table 9. Effect of lifetime chest Xray exposure (any exposure) on breast cancer risk according to the number of exposures, the age at first exposure and the first full-term pregnancy by status of tumor estrogen receptors, after imputation of missing data. Supplemental Table 10. Effect of lifetime chest X-ray exposure (any exposure) on breast cancer risk according to the number of exposures, the age at first exposure and the first full-term pregnancy among cases diagnosed within 5 years before enrollment in GENESIS. Supplemental Table 11. Sensitivity analyses with varying bounds of OR for the definition of genetic variant group: effect of lifetime chest $X$-ray exposure (any exposure) on breast cancer risk according to the number of exposures, the age at first exposure and the first full-term pregnancy. Supplemental Table 12. Sensitivity analyses by variants group, excluding variants from the 'High' Group in genes individually statistically (or borderline) associated with an increased risk of breast cancer in GENESIS population.

\section{Acknowledgements}

We wish to thank the genetic epidemiology platform (the PIGE, Plateforme d'Investigation en Génétique et Epidémiologie: S. Eon-Marchais, M. Marcou, D. Le Gal, L. Toulemonde, J. Beauvallet, N. Mebirouk, E. Cavaciuti, A. Fescia), the biological resource center (C. Verny-Pierre, L. Barjhoux, V. Sornin, N. Mebirouk, F. Lesueur), and all the GENESIS collaborating cancer clinics (Clinique Sainte Catherine, Avignon: H. Dreyfus; Hôpital Saint Jacques, Besançon: M-A. Collonge-Rame; Institut Bergonié, Bordeaux: M.Longy, A. Floquet, E. Barouk-Simonet; CHU, Brest: S. Audebert; Centre François Baclesse, Caen: P. Berthet; Hôpital Dieu, Chambéry: S. Fert-Ferrer; Centre Jean Perrin, ClermontFerrand: Y-J. Bignon; Hôpital Pasteur, Colmar: J-M. Limacher; Hôpital d'Enfants $\mathrm{CHU}$ - Centre Georges François Leclerc, Dijon: L. Faivre-Olivier; CHU, Fort de France: O. Bera; CHU Albert Michallon, Grenoble: D. Leroux; Hôpital Flaubert, Le Havre: V. Layet; Centre Oscar Lambret, Lille: P. Vennin ${ }^{\dagger}$, C. Adenis; Hôpital Jeanne de Flandre, Lille: S. Lejeune-Dumoulin, S. Manouvier-Hanu; CHRU Dupuytren, Limoges: L. Venat-Bouvet; Centre Léon Bérard, Lyon: C. Lasset, V. 
Bonadona; Hôpital Edouard Herriot, Lyon: S. Giraud; Institut Paoli-Calmettes, Marseille: F. Eisinger, L. Huiart; Centre Val d'Aurelle - Paul Lamarque, Montpellier: I. Coupier; CHU Arnaud de Villeneuve, Montpellier: I. Coupier, P. Pujol; Centre René Gauducheau, Nantes: C. Delnatte; Centre Catherine de Sienne, Nantes: A. Lortholary; Centre Antoine Lacassagne, Nice: M. Frénay, V. Mari; Hôpital Caremeau, Nîmes: J. Chiesa; Réseau Oncogénétique Poitou Charente, Niort: P. Gesta; Institut Curie, Paris: D. Stoppa-Lyonnet, M. Gauthier-Villars, B. Buecher, A. de Pauw, C. Abadie, M.Belotti; Hôpital Saint-Louis, Paris: O. Cohen-Haguenauer; Centre Viggo-Petersen, Paris: F. Cornélis; Hôpital Tenon Paris: A. Fajac; GH Pitié Salpétrière et Hôpital Beaujon, Paris: C. Colas, F. Soubrier, P. Hammel, A. Fajac; Institut Jean Godinot, Reims: C. Penet, T. D. Nguyen; Polyclinique Courlancy, Reims: L. Demange ${ }^{\dagger}$, C. Penet; Centre Eugène Marquis, Rennes: C. Dugast; Centre Henri Becquerel, Rouen: A. Chevrier, T. Frebourg ${ }^{+\dagger}$, J. Tinat, I. Tennevet, A. Rossi; Hôpital René Huguenin/ Institut Curie, Saint Cloud: C. Noguès, L. Demange ${ }^{\dagger}$, E. Mouret-Fourme; CHU, Saint-Etienne: F. Prieur; Centre Paul Strauss, Strasbourg: J-P. Fricker, H. Schuster; Hôpital Civil, Strasbourg: O. Caron, C. Maugard; Institut Claudius Regaud, Toulouse: L. Gladieff, V. Feillel; Hôpital Bretonneau, Tours: I. Mortemousque; Centre Alexis Vautrin, Vandoeurre-les-Nancy: E. Luporsi; Hôpital de Bravois, Vandoeuvre-les-Nancy: P. Jonveaux; Gustave Roussy, Villejuif: A. Chompret ${ }^{\dagger}$, O. Caron).

We wish to pay tribute to Olga M. Sinilnikova who was one of the initiators and principal investigators of GENESIS and who died prematurely on June 30, 2014.

Finally, we are very indebted to Dr. Alisa Goldstein (Clinical Genetics Branch, Division of Cancer Epidemiology and Genetics, National Cancer Institute, National Institutes of Health, Bethesda, MD, USA) for agreeing to review and proofread this manuscript.

${ }^{+}$: deceased prematurely

${ }^{++}$: suddenly passed away on March 13, 2021.

\section{Authors' contributions}

MRG and NA were responsible for the analyses, conducted the statistical analyses and wrote the report. DSL and NA led the GENESIS study and contributed to the protocol, design and search for funding. EC contributed to the protocol and design of the GENESIS study. NA and SEM were responsible for coordination of the study. DSL, BB, MGV, OC,CA, IC, PJ, CN, $E M F, V B, C L, P G, A L, C D, J P F, C M, L F, E L, M L, P B, C D, J T, C C, Y J B, V M, L V B, F E, D L$, $L G, S N H, I M, P P, T D N, J C, H D, S F F, L D, J L B, F S, V L, O C H, F P, F C, P J, O B$ are geneticists at family cancer clinics who made major contributions to the invitation of index cases. SEM, JB, DL and NM were responsible for inclusion of participants, data collection and data entry. AT provided expertise for Xray exposures. MGD was responsible for data checking and preparation. SM $L B, F D, N M$ and $F L$ were responsible for the biological resource center and FL for the strategy to identify and classify the DNA repair gene variants. JC, FL provided critical readings of the manuscript and writing support. All authors reviewed the report critically and approved the final version of the manuscript.

\section{Funding}

The Brazilian National Council for the Improvement of Higher Education CAPES, for the fellowship (process number: BEX 5852/15-3) to M.R. Guerra. Financial support for GENESIS was provided by the Ligue Nationale contre le Cancer (3 grants: PRE05/DSL and PRE07/DSL to D. Stoppa-Lyonnet; PRE11/NA to N. Andrieu), the French National Institute of Cancer (INCa, Grant b2008029/LL-LC), and the comprehensive cancer center SiRIC (Site de Recherche Intégrée sur le Cancer: Grant INCa-DGOS-4654) to N. Andrieu.

\section{Availability of data and materials}

The data underlying this article will be shared on reasonable request to the corresponding author.

\section{Declarations}

\section{Ethics approval and consent to participate}

The study protocol was approved by the appropriate ethics committee (Comité de Protection des Personnes Ile-de-France III, 3 October 2006, agreement $n^{\circ} 2373$ ). Written informed consent was obtained for all women included in the study.

\section{Consent for publication}

Not applicable

\section{Competing interests}

The authors declare that they have no competing interests.

\section{Author details}

${ }^{1}$ INSERM, U900, Paris, France. ${ }^{2}$ Institut Curie, Paris, France. ${ }^{3}$ Mines ParisTech, Fontainebleau, France. ${ }^{4}$ PSL Research University, Paris, France. ${ }^{5}$ Department of Public Health, Faculty of Medicine, Federal University of Juiz de Fora UFJF, Minas Gerais, Brazil. 'Institut Curie, Service de Génétique, Paris, France. ${ }^{7}$ Gustave Roussy, Département de Médecine Oncologique, Université Paris-Saclay, Villejuif, France. ${ }^{8}$ Hôpital Arnaud de Villeneuve, CHU Montpellier, Service de Génétique Médicale et Oncogénétique, Montpellier, France. ${ }^{9}$ INSERM 896, CRCM Val d'Aurelle, Montpellier, France. ${ }^{10}$ Centre Catherine de Sienne, Service d'Oncologie Médicale, Nantes, France. ${ }^{11}$ Centre Paul Strauss, Unité d'Oncologie, Strasbourg, France. ${ }^{12} \mathrm{CH}$ Georges Renon, Service d'Oncogénétique Régional Poitou-Charentes, Niort, France. ${ }^{13}$ Département d'Anticipation et de Suivi des Cancers, Oncogénétique Clinique, Institut Paoli Calmettes, Marseille, France. ${ }^{14}$ Aix Marseille Univ, INSERM, IRD, SESSTIM, Marseille, France. ${ }^{15}$ Institut GIMI, CHU de Dijon, Hôpital d'Enfants, Dijon, France. ${ }^{16}$ Centre de Lutte contre le Cancer Georges François Leclerc, Dijon, France. ${ }^{17}$ Centre François Baclesse, Unité de pathologie gynécologique, Caen, France. ${ }^{18}$ Service de Génétique UF4128 CHR Metz-Thionville, Hôpital de Mercy, Metz, France. ${ }^{19}$ Centre René Gauducheau, Unité d'Oncogénétique, Nantes, Saint Herblain, France. ${ }^{20}$ Université Claude Bernard Lyon 1, Villeurbanne, France. ${ }^{21}$ CNRS UMR 5558, Lyon, France. ${ }^{22}$ Centre Léon Bérard, Unité de Prévention et Epidémiologie Génétique, Lyon, France. ${ }^{23}$ Génétique Oncologique moléculaire, UF1422, Département d'Oncobiologie, LBBM, Hôpitaux Universitaires de Strasbourg, Strasbourg, France. ${ }^{24}$ UF6948 Génétique Oncologique Clinique, Evaluation familiale et suivi, Hôpitaux Universitaires de Strasbourg, Strasbourg, France. ${ }^{25}$ Institut Bergonié, Bordeaux, France. ${ }^{26}$ Département d'oncogénétique, Centre Jean Perrin, Université Clermont Auvergne, UMR INSERM 1240, Clermont Ferrand, France. ${ }^{27}$ Polyclinique de la Louvière (groupe Ramsay), Lille, France. ${ }^{28}$ Service d'Oncologie Médicale, Hôpital Universitaire Dupuytren, Limoges, France. ${ }^{29}$ Clinique Sainte Catherine, Avignon, France. ${ }^{30}$ Hôpital Couple-Enfant, Département de Génétique, CHU de Grenoble, Grenoble, France. ${ }^{31}$ Institut Claudius Regaud - IUCT-Oncopole, Service d'Oncologie Médicale, Toulouse, France. ${ }^{32}$ Service de Génétique, Hôpital Bretonneau, Tours, France.

${ }^{33}$ Département de Génétique Médicale et Biologie de la Reproduction, Hôpital Morvan, CHU Brest, Brest, France. ${ }^{34}$ Hôpital Tenon, Paris, France. ${ }^{35}$ Hospices Civils de Lyon, Service de Génétique, Groupement Hospitalier EST, Bron, France. ${ }^{36}$ Clinique de Génétique Médicale Guy Fontaine, CHU Lille, Lille, France. ${ }^{37}$ Service d'Onco-hématologie, Hôpital Pasteur, Colmar, France. ${ }^{38}$ Service d'Oncologie Médicale, CHRU Hôpital Caremeau, Nîmes, France. ${ }^{39}$ Service d'Oncogénétique, Hôpital Tenon, Paris, France. ${ }^{40}$ Groupe Hospitalier Pellegrin, Service de génétique médicale, CHU De Bordeaux, Bordeaux, France. ${ }^{41}$ Centre Hospitalier Métropole Savoie, Chambéry, France. ${ }^{42}$ Institut Curie, Hopital René Huguenin, Saint-Cloud, France. ${ }^{43}$ Département de Génétique, Hopital Universitaire de Rouen, Rouen, France. ${ }^{44}$ Department of Biopathology, Pathology Research platform, Centre Léon Bérard, Lyon, France. ${ }^{45}$ GCS AURAGEN, Plateforme de Génétique, Hôpital Edouart Herriot, Lyon, France. ${ }^{46}$ Centre de Recherche en Neurosciences de Lyon, INSERM U1028, CNRS UMR5292, Université Lyon 1, Université Saint Etienne, Lyon, France. ${ }^{47}$ Service de Radiologie, Institut Curie, Paris, France. ${ }^{48}$ INSERM, U830, Paris, France. ${ }^{49}$ Université Paris-Descartes, Paris, France.

Received: 1 February 2021 Accepted: 16 July 2021

Published online: 03 August 2021

\section{References}

1. Drooger JC, Hooning MJ, Seynaeve CM, Baaijens MH, Obdeijn IM, Sleijfer S, et al. Diagnostic and therapeutic ionizing radiation and the risk of a first and second primary breast cancer, with special attention for BRCA1 and BRCA2 mutation carriers: a critical review of the literature. Cancer Treat Rev. 2015;41(2):187-96. https://doi.org/10.1016/..ctrv.2014.12.002.

2. Gray JM, Rasanayagam S, Engel C, Rizzo J. State of the evidence 2017: an update on the connection between breast cancer and the environment. Environ Health. 2017;16(1):94. https://doi.org/10.1186/s12940-017-0287-4. 
3. Andrieu N, Easton DF, Chang-Claude J, Rookus MA, Brohet R, Cardis E, et al. Effect of chest $X$-rays on the risk of breast cancer among BRCA1/2 mutation carriers in the international BRCA1/2 carrier cohort study: a report from the EMBRACE, GENEPSO, GEO-HEBON, and IBCCS Collaborators' Group. J Clin Oncol. 2006;24(21):3361-6. https://doi.org/10.1200/JCO.2005.03.3126.

4. Lecarpentier J, Nogues C, Mouret-Fourme E, Stoppa-Lyonnet D, Lasset C, Caron $\mathrm{O}$, et al. Variation in breast cancer risk with mutation position, smoking, alcohol, and chest X-ray history, in the French National BRCA1/2 carrier cohort (GENEPSO). Breast Cancer Res Treat. 2011;130(3):927-38. https://doi.org/10.1007/s10549-011-1655-3.

5. Pijpe A, Andrieu N, Easton DF, Kesminiene A, Cardis E, Nogues C, et al. Exposure to diagnostic radiation and risk of breast cancer among carriers of BRCA1/2 mutations: retrospective cohort study (GENE-RAD-RISK). BMJ. 2012; 345:e5660. https://doi.org/10.1136/bmj.e5660.

6. $\mathrm{Ma} \mathrm{H}$, Hill CK, Bernstein L, Ursin G. Low-dose medical radiation exposure and breast cancer risk in women under age 50 years overall and by estrogen and progesterone receptor status: results from a case-control and a case-case comparison. Breast Cancer Res Treat. 2008;109(1):77-90. https:// doi.org/10.1007/s10549-007-9625-5.

7. Ronckers CM, Doody MM, Lonstein JE, Stovall M, Land CE. Multiple diagnostic $X$-rays for spine deformities and risk of breast cancer. Cancer Epidemiol Biomarkers Prev. 2008;17(3):605-13. https://doi.org/10.1158/10559965.EPI-07-2628.

8. Jansen-van der Weide MC, Greuter MJ, Jansen L, Oosterwijk JC, Pijnappel RM, de Bock GH. Exposure to low-dose radiation and the risk of breast cancer among women with a familial or genetic predisposition: a metaanalysis. Eur Radiol. 2010;20(11):2547-56. https://doi.org/10.1007/s00330-01 0-1839-y.

9. Boice JD Jr, Rosenstein M, Trout ED. Estimation of breast doses and breast cancer risk associated with repeated fluoroscopic chest examinations of women with tuberculosis. Radiat Res. 1978;73(2):373-90. https://doi.org/1 $0.2307 / 3574828$

10. Hill DA, Gilbert E, Dores GM, Gospodarowicz M, van Leeuwen FE, Holowaty E, et al. Breast cancer risk following radiotherapy for Hodgkin lymphoma: modification by other risk factors. Blood. 2005;106(10):3358-65. https://doi. org/10.1182/blood-2005-04-1535.

11. John EM, Phipps Al, Knight JA, Milne RL, Dite GS, Hopper UL, et al. Medical radiation exposure and breast cancer risk: findings from the Breast Cancer Family Registry. Int J Cancer. 2007;121(2):386-94. https:/doi.org/10.1002/ijc.22668.

12. Kenney LB, Yasui Y, Inskip PD, Hammond S, Neglia JP, Mertens AC, et al. Breast cancer after childhood cancer: a report from the Childhood Cancer Survivor Study. Ann Intern Med. 2004;141 (8):590-7. https://doi.org/10.7326/ 0003-4819-141-8-200410190-00006.

13. Gronwald J, Pijpe A, Byrski T, Huzarski T, Stawicka M, Cybulski C, et al. Early radiation exposures and BRCA1-associated breast cancer in young women from Poland. Breast Cancer Res Treat. 2008;1 12(3):581-4. https://doi.org/10.1 007/s10549-008-9892-9.

14. Narod SA, Lubinski J, Ghadirian P, Lynch HT, Moller P, Foulkes WD, et al. Screening mammography and risk of breast cancer in BRCA1 and BRCA2 mutation carriers: a case-control study. Lancet Oncol. 2006;7(5):402-6. https://doi.org/10.1016/S1470-2045(06)70624-6.

15. Goldfrank D, Chuai S, Bernstein JL, Ramon YC, Lee JB, Alonso MC, et al. Effect of mammography on breast cancer risk in women with mutations in BRCA1 or BRCA2. Cancer Epidemiol Biomarkers Prev. 2006;15(11):2311-3. https://doi.org/10.1158/1055-9965.EPI-06-0176.

16. Giannakeas V, Lubinski J, Gronwald J, Moller P, Armel S, Lynch HT, et al. Mammography screening and the risk of breast cancer in BRCA1 and BRCA2 mutation carriers: a prospective study. Breast Cancer Res Treat. 2014; 147(1):113-8. https://doi.org/10.1007/s10549-014-3063-y.

17. John EM, McGuire V, Thomas D, Haile R, Ozcelik H, Milne RL, et al. Diagnostic chest $X$-rays and breast cancer risk before age 50 years for BRCA1 and BRCA2 mutation carriers. Cancer Epidemiol Biomarkers Prev. 2013;22(9):1547-56. https://doi.org/10.1158/1055-9965.EPI-13-0189.

18. Colin C, Foray N, Di Leo G, Saranelli F. Radiation induced breast cancer risk in BRCA mutation carriers from low-dose radiological exposures: a systematic review. Radioprotection. 2017;52(4):231-40. https://doi.org/10.1 051/radiopro/2017034

19. Sinilnikova OM, Dondon MG, Eon-Marchais S, Damiola F, Barihoux L, Marcou $M$, et al. GENESIS: a French national resource to study the missing heritability of breast cancer. BMC Cancer. 2016;16(1):13. https://doi.org/10.11 86/s12885-015-2028-9.
20. Girard E, Eon-Marchais S, Olaso R, Renault AL, Damiola F, Dondon MG, et al. Familial breast cancer and DNA repair genes: insights into known and novel susceptibility genes from the GENESIS study, and implications for multigene panel testing. Int J Cancer. 2019;144(8):1962-74. https://doi.org/10.1002/ ijc.31921.

21. Van BS, Boshuizen HC, Knook DL. Multiple imputation of missing blood pressure covariates in survival analysis. Stat Med. 1999;18(6):681-94.

22. Raghunathan TE. What do we do with missing data? Some options for analysis of incomplete data. Annu Rev Public Health. 2004;25(1):99-117. https://doi.org/10.1146/annurev.publhealth.25.102802.124410.

23. StataCorp. 2015. Stata: Release 14. Statistical software. College Station, TX: StataCorp LP. 2015.

24. Roderick J. A. Little, Donald B. Rubin. Statistical analysis with missing data. Second Edition ed. John Wiley \& Sons, Inc.; 2002.

25. Rubin DB, Schenker N. Multiple imputation in health-care databases: an overview and some applications. Stat Med. 1991;10(4):585-98. https://doi. org/10.1002/sim.4780100410.

26. Miki Y, Swensen J, Shattuck-Eidens D, Futreal PA, Harshman K, Tavtigian S, et al. A strong candidate for the breast and ovarian cancer susceptibility gene BRCA1. Science. 1994;266(5182):66-71. https://doi.org/10.1126/science. 7545954.

27. Wooster R, Bignell G, Lancaster J, Swift S, Seal S, Mangion J, et al. Identification of the breast cancer susceptibility gene BRCA2. Nature. 1995; 378(6559):789-92. https://doi.org/10.1038/378789a0.

28. Sigurdson AJ, Bhatti P, Chang SC, Rajaraman P, Doody MM, Bowen L, et al. Polymorphisms in estrogen biosynthesis and metabolism-related genes, ionizing radiation exposure, and risk of breast cancer among US radiologic technologists. Breast Cancer Res Treat. 2009;1 18(1):177-84. https://doi.org/1 0.1007/s10549-009-0307-3.

29. Norman SA, Localio AR, Zhou L, Bernstein L, Coates RJ, Flagg EW, et al. Validation of self-reported screening mammography histories among women with and without breast cancer. Am J Epidemiol. 2003;158(3):26471. https://doi.org/10.1093/aje/kwg136.

30. Pogoda JM, Preston-Martin S. Radiation exposure from diagnostic imaging: agreement between self-report and medical records. Health Phys. 2002; 83(6):907-17. https://doi.org/10.1097/00004032-200212000-00019.

31. de GA B, Ekbom A, Glass AG, Galanti MR, Grimelius L, Allison MJ, et al. Comparison of documented and recalled histories of exposure to diagnostic X-rays in case-control studies of thyroid cancer. Am J Epidemiol. 2003;157(7):652-63.

32. IARC Working Group on the Evaluation of Carcinogenic Risks to Human. IARC Monogr Eval Carcinog Risks Hum 2012; 100(Pt D):7-303.

\section{Publisher's Note}

Springer Nature remains neutral with regard to jurisdictional claims in published maps and institutional affiliations.

Ready to submit your research? Choose BMC and benefit from:

- fast, convenient online submission

- thorough peer review by experienced researchers in your field

- rapid publication on acceptance

- support for research data, including large and complex data types

- gold Open Access which fosters wider collaboration and increased citations

- maximum visibility for your research: over $100 \mathrm{M}$ website views per year

At BMC, research is always in progress.

Learn more biomedcentral.com/submissions 